Вітюк Д. Л., Павлюх О. А. Вибори як форма безпосередньої демократії: теоретико-правовий аспект

Актуальність обраної теми дослідження полягає у тому, що вибори - найефективніша форма безпосередньої демократії як в Україні, так і в інших державах.

У статті досліджується поняття виборів та соціальні функції виборів. Визначено критерії поділу виборів та охарактеризовано види виборів. Розкрито поняття «виборче право» та визначено його роль у контексті проведення виборів для формування органів державної влади. Висока суспільна-політична цінність виборів проявляється у характеристиці основних принципів виборчого права. Шляхом розгляду принципу загальності виборчого права підтверджено доцільність застосування виборчих цензів під час виборів. Розкрито поняття «виборчий процес» та охарактеризовано стадії виборчого процесу. Досліджено компетенцію органів, які обслуговують виборчий процес.

Стаття сприяє формуванню фундаментальних знань про функціонування виборів в Україні та зарубіжних країнах. Шляхом аналізу практики світового досвіду реалізації виборчого права під час виборів проведено прогнозування перспектив організації державної влади в Україні.

Ключові слова: вибори, форма безпосередньої демократії, абсентеїзм, виборче право, активне виборче право, пасивне виборче право, виборчий процес, виборча система.

Vityuk D. L., Pavlyukh O. A. Elections as a Form of Direct Democracy: the Theoretical and Legal Aspect

The relevance of a subject of a research is that elections an effective form of direct democracy both in Ukraine, and in other states.

In article the concept of elections and social functions of elections is investigated. Criteria of division of elections are defined and types of elections are characterized. The concept «electoral right» is opened and its role in the context of elections for formation of public authorities is defined. High social political value of elections is shown in characteristic of the basic principles of an electoral right. By consideration of the principle of generality of an electoral right the expediency of use of voting qualifications on elections is confirmed. The concept «selective process» is opened and stages of electoral process are characterized. The competence of the bodies serving electoral process is investigated.

Article promotes formation of fundamental knowledge of functioning of elections in Ukraine and foreign countries. By the analysis of practice of international experience of realization of an electoral right on elections forecasting of prospects of the organization of the government in Ukraine is carried out.

Key words: elections, form of direct democracy, absenteeism, suffrage, active suffrage, passive electoral right, electoral process, electoral system.

DOI: 10.33.66.3/2524-017X-2019-10-115-121

УДК 340.12; 321.01

Оксана Федорівна Данич, аспірантка відділу теорії держави і права Інституту держсави і права ім. В.М. Корецьккого НАН України

\title{
ДО ПИТАННЯ ПРО РОЛЬ ПРАВОВОЇ СИСТЕМИ У ЗАБЕЗПЕЧЕННІ СОЦІАЛЬНОӤ ФУНКЦЇ̈ ДЕРЖАВИ: ГЛОБАЛІЗАЦІЙНИЙ ВИМІР
}

Постановка проблеми. Однією з необхідних складових ефективного функціонування суспільства і держави, беззаперечно, є розвинена національна правова система з ії класичним центральним елементом - правом. В сучасних умовах саме праву та правовій системі належить особливе, самостійне місце серед інших соціальних явищ, оскільки на правову систему покладається основний тягар нормативного регулювання різноманітних суспільних відносин, забезпечення індивідуальних, групових та загальних (національних, державних) інтересів, а також вирішення виникаючих у суспільстві соціальних конфліктів. При цьому особливу роль правова система відіграє у забезпеченні нормативної регламентації різноманітних глобалізаційних процесів, у тому числі тих, які пов'язані з проблемами реалізації соціальної функції сучасних держав в умовах посилення «полярних» тенденцій розвитку соціальних відносин. 
Аналіз останніх досліджень та публікацій. Необхідно зазначити, що питання впливу правової системи та її складових на ефективність здійснення функцій сучасної держави, у тому числі соціальної, вже стали предметом розгляду багатьох вітчизняних та зарубіжних науковців, серед яких потрібно назвати: К. Бабенко, О. Волошенюк, Т. Ендікотт, А. Краковська, Н. Оніщенко, Н. Пархоменко, Ю. Тихомиров, Н. Хома, М. Шумило, О. Ющик тощо. Не применшуючи величезного значення наукового доробку цих та багатьох інших вчених, потрібно констатувати необхідність переосмислення деяких підходів, пов'язаних із визначенням характеру впливу правової системи на ефективність здійснення соціальної функції держави в умовах сучасної глобалізації.

Мета статті. Метою цієї статті $є$ визначення ролі та значення правової системи у забезпеченні соціальної функції держави з урахуванням сучасних глобалізаційних процесів.

Основні результати дослідження. Мабуть, беззаперечним слід визнати, що успішне вирішення багатоманітних соціальних завдань, які стоять перед державою та громадянським суспільством, безпосередньо залежить від того, наскільки ефективно здійснюється правове регулювання соціальних відносин, наскільки захищеними та забезпеченими є громадяни відповідної держави, наскільки чітко та недвозначно регламентовано всі процедури, пов'язані із наданням соціальної допомоги, здійсненням соціального захисту та соціального забезпечення тощо [1, с. 3 ; 2, с. 396$]$. Так зване «соціальне право» сприяє забезпеченню людської гідності кожного не лише перед загрозою державно-владного вторгнення, а й у повсякденній боротьбі за гідні умови життя людей; воно повинно бути гарантом рівності громадян у державі, реальне забезпечення якої $є$ неможливим без практичного втілення ідеї добробуту; воно означає задоволення потреб і розвиток здібностей кожної людини за умови, що вільний розвиток індивіда гармонійно поєднуватиметься зі свободою інших осіб [3, с. 9-13].

На особливу значущість правової складової у забезпеченні належного здійснення соціальної функції держави звертають увагу низка вітчизняних вчених. Зокрема, Н. Оніщенко та Н. Пархоменко зазначають, що правова система соціальної, правової держави покликана забезпечити встановлену соціальною політикою стабільність громадянської згоди шляхом проголошення, реалізації і охорони соціально-правових умов для стимулювання активної частини населення на продуктивну працю як основу особистого добробуту; підтримання оптимального співвідношення між прибутками працездатної частини суспільства та непрацездатними громадянами; надання адресної соціальної підтримки; скорочення та обмеження масштабів зубожіння; забезпечення прожиткового мінімуму громадян [4, с. 10-11].

Таким чином, правове i, насамперед, конституційне визнання будь-якої держави соціальною фактично вносить суттєві корективи в умови формування відносин між державою та громадянином, оскільки держава бере на себе зобов'язання в межах наявних у неї засобів забезпечувати соціальні та економічні права громадян, гарантувати гідне життя кожному громадянину, а також відповідний рівень соціальної захищеності та соціальної безпеки. Крім цього, відносини всередині суспільства та держави також пов'язані 3 необхідністю формування у соціальному середовищі атмосфери соціальної солідарності та взаємної допомоги, коли запорукою достатку для кожної окремої особистості вважається матеріальний добробут або принаймні достатній життєвий рівень для всіх членів суспільства [5, с. 430].

На нашу думку, досліджувати роль та значення правової системи у забезпеченні функцій держави взагалі та соціальної функції зокрема, потрібно виходячи не лише 3 аспекту встановлення у відповідних правових нормах правил регулювання соціальної сфери суспільного життя, а й враховуючи правореалізаційну i, особливо, правозастосовну діяльність уповноважених суб'єктів, спрямовану на забезпечення ефективного функціонування соціальної політики в державі. Якщо ж вести мову про наукове осмислення ролі та значення правової системи у забезпеченні соціальної функції держави в умовах глобалізації, то в цьому випадку, на нашу думку, правовий вплив не може обмежуватися лише національними (внутрішніми) параметрами або, якщо говорити узагальнено, механізмами. Адже глобалізація - це всесвітній процес якісних змін всіх основних сфер соціального життя, спрямований на їх об'єднання або, принаймні, поєднання в межах конкретно визначених правових, інституційних, ідеологічних та інших засад. Об'єктивність даного процесу поступово зміщує або, щонайменше, видозмінює регулятивно-охоронні можливості національних правових систем, пов'язані із впливом на суспільні відносини в цілому і соціальні відносини зокрема. Враховуючи той факт, що внаслідок глобалізаційних процесів суттєво посилюється роль та значення 
Данич О. Ф. До питання про роль правової системи у забезпеченні соціальної функції держави...

міжнародного або наднаціонального права, особливої актуальності набувають питання, пов'язані з вирішенням проблеми співвідношення національного та міжнародного (наднаціонального) права i, відповідно, національних та наднаціональних правових систем в цілому, які дедалі активніше проявляють себе на міжнародній арені (наприклад, правова система Європейського Союзу).

Сучасна правова реальність переконливо доводить, що на сьогодні, в умовах посилення глобалізаційних процесів, норми міжнародного права, норми наднаціональних державних об'єднань на кшталт Європейського Союзу, усе частіше стають зразком для забезпечення правового регулювання на національному рівні, тобто на рівні окремих держав. Як зазначають окремі вітчизняні вчені, «саме в національній правовій системі великий масив абстрактних норм міжнародного права набуває свого реального значення як для певної держави, так і для міжнародного співтовариства в цілому» [6, с. 64].

Цілком очевидним слід визнати, що розвиток і ефективна реалізація права як цілісного системного нормативного утворення, вираженого у встановлених формах, є можливою лише за умови внутрішньої несуперечливості та узгодженості його елементів i, насамперед, правових норм. При цьому мова повинна йти не стільки про ієрархічну узгодженість правових норм між собою, скільки про їх змістовну узгодженість, особливо в межах нормативно-правових актів чи правових прецедентів, які мають однакову юридичну силу. Колізійність та змістовна неузгодженість правових норм між собою, незалежно від того, на якому рівні зазначене має місце (національно чи міжнародному), призводить до дисбалансу правового регулювання в цілому, що значно знижує його практичну ефективність. Зрозуміло, що без такої узгодженості всієї системи права, що особливо яскраво проявляється на рівні правових норм, неможливо вести мову про повноцінну ефективність здійснення будь-яких функцій держави, у тому числі соціальної.

Слід погодитися з Н. Оніщенко, що успішне правове регулювання внутрішньодержавних відносин в наш час стає все більш залежним від узгодженості норм національного права 3 міжнародним правом, що, у свою чергу, обумовлюється низкою глобальних чинників, а саме: 1) задачею виживання людської цивілізації, подолання агресивних проявів з боку деяких держав, необхідністю підтримання міжнародного миру, світового правопорядку, безпеки; 2) усвідомленням пріоритетності загальнолюдських цінностей, поваги до прав, свобод та законних інтересів людини, необхідністю підтримання в межах всього людства справедливості, стабільності і демократії; 3) інтернаціоналізацією виробництва, науки і обміну технологічними досягненнями; 4) задачею охорони навколишнього природного середовища; 5) міжнародним культурним співробітництвом [7, с. 80].

Необхідно також відзначити, що міжнародне право впливає на національне не лише шляхом визначення конкретних юридичних процедур імплементації його положень у внутрішнє право держави, а й телеологічно, тобто через визначення цільової ціннісної парадигми розвитку національного права $[8$, с. 56-66]. На теперішній час такими загальними телеологічними установками міжнародного права, які так чи інакше пронизують абсолютну більшість сучасних національних правових систем, слід визнати: забезпечення і захист прав і свобод людини як пріоритет діяльності держави і громадянського суспільства, демократизація суспільного і державного життя, лібералізація економіки тощо. Адже, як вказується у сучасній науковій літературі, «телеологічними детермінантами розвитку правової системи виступають цінності, що існують в межах об'єктивної реальності суспільної свідомості», до яких належать, зокрема, свобода, справедливість, рівність, гуманізм, природні права людини [9, с. 315-317], демократія, ринкова економіка тощо.

Враховуючи беззаперечний факт, що більшість з названих ідеальних понять та одночасно реальних аспектів (зрізів) соціального життя, перебувають під впливом не лише права як найбільш дієвого соціального регулятора, а й інших нормативно-ціннісних компонентів культури (наприклад, моралі, звичаїв, традицій), то у процесі взаємовпливу міжнародного і національного права виникає об'єктивна необхідність забезпечити відповідне узгодження вказаних ціннісних засад, які по-різному проявляються в різних культурах. Адже незалежно від того, $є$ право національним або міжнародним (глобальним), які засади в ньому є переважаючими (міжнародні, регіональні, національні), головне, щоб його зміст відповідав інтересам, прагненням та вимогам конкретного суспільства, що, у свою чергу, забезпечує його реальну дієвість [10, с. 2]. У протилежному ж випадку право, незалежно від його виміру, залишатиметься лише відповідною декларацією про «добрі наміри».

Так, у науковій літературі зазначається, що одним із способів впровадження міжнародних стандартів у сфері соціального захисту є гармонізація національного законодавства 3 міжнародними 
нормативно-правовими актами, яка може здійснюватися кількома шляхами: пряме застосування після ратифікації, включення в текст законів, імплементація положень ратифікованих чи нератифікованих актів за допомогою національного законодавства [11, с. 244].

У вказаному контексті потрібно з'ясувати питання щодо змісту поняття гармонізація національного законодавства, що регулює різноманітні аспекти функціонування і розвитку соціальної сфери, з відповідними міжнародно-правовими актами, а також визначити характер взаємозв'язку поняття «гармонізація законодавства» 3 іншими близькими за змістом поняттями, зокрема, 3 поняттям «уніфікація законодавства».

Як відомо, термін «гармонізація» походить від грецького слова «harmonikos», що означає злагоджений, розмірний. Завдяки гармонізації забезпечується такий стан національного законодавства, при якому його акти за своїм змістом, принципами правового регулювання й передбачуваними результатами у правозастосовній практиці є однорідними актам іншої країни або міжнародного об'єднання при можливому розходженні юридичних методів досягнення результату. При даній формі зближення законодавства норми різних країн можуть мати несхоже звучання, але бути «співзвучними», тобто разом створювати своєрідний «гармонійний акорд» [12, с. 4].

Досліджуючи проблему визначення основних способів європейської правової інтеграції, Л. Луць також пропонує звертатися до лексичного значення понять «гармонізація» та «уніфікація». Так, термін «гармонія» означає «поєднання, злагодженість, взаємна відповідність якостей, предметів, явищ, частин цілого». Отже, гармонізація - це сукупність дій щодо досягнення гармонії, балансу та рівноваги, усунення суперечностей [13, с. 146-148]. За словами Н. Кузнєцової, гармонізація законодавства являє собою усунення проблематичних невідповідностей між національними законами. Це зовсім не означає створення абсолютно однакових законодавчих положень, а означає, що їх зміст повинен бути достатньо схожим з метою забезпечення єдиних стандартів законодавчого регулювання. Гармонізація законодавства у визначеній мірі призводить до «ідеологічного» зближення законів, а також окремих правових норм, певних юридичних механізмів [14, с. 67].

Уніфікація законодавства, на відміну від гармонізації, передбачає приведення національних актів між собою або з нормами міжнародного права чи інших держав у такий стан, за якого вони повністю збігатимуться. Таким чином, якщо гармонізація передбачає усунення суттєвих протиріч між юридичними джерелами різних держав (горизонтальна гармонізація) або ж між джерелами національного та міжнародного права (вертикальна гармонізація) при збереженні певних особливостей, то уніфікація спрямована на створення одноманітних, ідентичних правових норм. Уніфіковані норми поділяються на матеріально-правові, процесуальні та колізійні. При цьому останні не забезпечують єдності правового регулювання, але створюють єдині колізійні критерії та відсилання до певного іноземного закону [15, с. 163]. Уніфікація законодавства може бути універсальна та регіональна, вона знаходить прояв у створенні єдиних нормативних актів, виробленні їх єдиної системи та структури, розширенні кола загальних норм, забезпеченні смислової однозначності правових приписів та уніфікації правової термінології, розробці примірних нормативних актів тощо. При цьому можливі два механізми уніфікації: неформальне запозичення (наприклад, в ситуації, коли представники правотворчих і правозастосовних органів співпрацюють у підготовці нормативних актів або при розробці модельного законодавства) і запозичення внаслідок прямого зобов'язання, яке відбувається при ратифікації міжнародних договорів або в процесі приєднання до наддержавного об'єднання. Інструментом уніфікації виступають також міжнародні торгові звичаї, які широко застосовуються в галузі торговельного мореплавства та міжнародних розрахунках і які в тій чи іншій мірі сприяють уніфікації права як більш широкого у порівнянні з системою законодавства нормативного утворення, забезпечують єдність у вирішенні багатьох важливих практичних питань [12, с. 5].

За словами О. Ющика, необхідність уніфікації у праві виникає при утворенні нових держав, на території яких діють складові різних правових систем; при формуванні єдиної правової системи союзних держав; у процесі зближення правових систем держав, які утворюють різні міждержавні об'єднання; у правовому регулюванні зовнішньоекономічних відносин тощо [16, с. 945].

3 означеного вище випливає, що, по-перше, гармонізація законодавства не означає тотожності (однаковості) або ідентичності змісту правових норм різних нормативних актів, а передбачає зменшення відмінностей між ними, поєднання та взаємне доповнення їх смислового навантаження 3 метою забезпечення цілісності та узгодженості правового регулювання відповідної сфери суспільних відносин і, по-друге, гармонізація законодавства повинна передувати його уніфікації, особливо у контексті співставлення норм національного та міжнародного права або норм націо- 
Данич О. Ф. До питання про роль правової системи у забезпеченні соціальної функції держави...

нального законодавства з нормами законодавства інших держав, а остання (уніфікація), у разі наявності міжнародної складової, може застосовуватися лише у випадку досягнення позитивного досвіду гармонізації законодавства, тобто як остаточне закріплення її позитивних результатів у формі створення єдиних (однакових, уніфікованих) правових норм. При цьому, на нашу думку, повинні враховуватися наступні положення:

1) термін «гармонізація», так само як і «уніфікація», може застосовуватися не лише щодо системи законодавства, а й щодо права та правової системи в цілому. В останньому випадку потрібно вести мову про координацію, зближення, зменшення або повне усунення розбіжностей між певною сукупністю відповідних елементів, що складають поняття «правова система»;

2) як гармонізація, так і уніфікація законодавства в умовах глобалізації, а тим більше якщо мова йде про правові системи в цілому, мають відбуватися не в односторонньому порядку, тобто, наприклад, через покладення лише обов’язків на відповідну країну щодо здійснення конкретних дій, спрямованих на забезпечення узгодженості законодавства, а шляхом здійснення взаємних кроків щодо подолання суперечностей, які містяться у законодавстві або, наприклад, у порядку його застосування. По суті, односторонній характер гармонізації можна виокремлювати лише умовно, оскільки «досягнення гармонії», злагодженості, узгодженості між нормативними системами відповідного рівня неможливо здійснити шляхом нав'язування відповідних норм іншій стороні, зокрема, державі. Така «псевдогармонізація» матиме здебільшого негативні наслідки для суб'єкта (наприклад, держави), який лише зобов'язаний здійснити відповідні дії для забезпечення «гармонійного» правового регулювання;

3) гармонізація та уніфікація, незалежно від рівня їх застосування у правовому контексті, мають враховувати не лише особливості конкретної правової реальності в межах визначених темпорально-просторових вимірів, зокрема, особливості розвитку галузей та інститутів приватного і публічного права, особливості реалізації окремих принципів права в межах відповідної держави тощо, але й об' єктивні параметри функціонування таких підсистем соціального розвитку, як економічна, політична, культурна, моральна, релігійна тощо. Забезпечуючи здійснення процесу гармонізації, а тим більше уніфікації правового регулювання, в жодному разі не потрібно прагнути до створення так званої моделі всесвітнього або глобального права, яке є об'єктивно неможливим у зв'язку iз величезною розмаїтістю національних культурних, а отже, і правових практик. Таке тотально уніфіковане, глобальне або всесвітнє право, норми якого поширюють свою загальнообов'язковість на всі без винятку держави, можливо створити лише внаслідок свідомого суб'єктивного втручання у відповідні процеси з боку наймогутніших держав світу, які задають стандарти соціального розвитку та їх правове оформлення. Як свідчить сучасна міжнародна практика, яка має місце в межах відповідних регіонів світу, спроби механічного перенесення однієї моделі державно-правового розвитку у площину зовсім іншої культурної парадигми, як правило, призводить до трагічних соціальних наслідків у вигляді руйнування національних соціально-економічних систем, поширення бідності, масової міграції, у тому числі за межі одного континенту та навіть громадянських війн. 3 цього випливає, що до процесів гармонізації та уніфікації у праві чи законодавстві національні держави мають залучатися на добровільній та двосторонній основі, враховуючи неоднозначність практичних наслідків цих процесів.

Висновки. Таким чином, при забезпеченні соціальної функції держави в умовах глобалізації національна правова система виконує найважливішу роль, яку не можна обмежувати лише характером ії внутрішнього впливу на здійснення соціальної політики, оскільки особливої значущості в умовах глобалізації набувають різноманітні питання, пов’язані з конвергенцією правових систем між собою, поступовим формуванням на цій основі наднаціональних або міжнародних правових систем, а також ускладненням взаємозв'язків між міжнародним та національним правом у зв'язку iз об’єктивністю відображення в останньому історичних, економічних, соціальних, культурних, релігійних та інших особливостей суспільного розвитку.

\section{Список використаних джерел}

1. Бабенко К. Конституційні основи розвитку та регулювання соціальних відносин // Віче. - 2008. - № 2. - С. 3-6.

2. Краковська А. С. Соціальні права людини і громадянина як визначальна детермінанта еволюції соціальної функції держави // Вісник Донецького національного університету. - Серія В: економіка і право. - 2002. Вип. 2. - С. 394-399. 
3. Цахер $X . \Phi$. Социальное право и справедливость // Общественные науки за рубежом. - Сер. 4. Государство и право. - М. : ИНИОН АН СССР, 1990. - № 3. - С. 9-13.

4. Оніщенко Н. М., Пархоменко Н. М. Соціальний вимір правової системи: реалії та перспективи : моногр. / відп ред. Ю. С. Шемшученко. - К. : Вид-во «Юридична думка», 2011. - 176 с.

5. Хома Н. М. Моделі соціальної держави: світовий та український досвід: монографія. - К. : Вид-во «Юридична думка», 2012. -592 с.

6. Денисов В. Н. Міжнародне право як складова частина правової системи України // Проблеми гармонізації законодавства України з міжнародним правом : матеріали наук.-практ. конф. (жовтень, 1998). - К. : Ін-т законодавства Верховної Ради України, 1998. - С. 64-68.

7. Оніщенко Н. М. До проблеми взаємовідповідності внутрішньодержавного і міжнародного права (теоретикоправовий аспект) // Міжнародний правопорядок: сучасні проблеми та їх вирішення. Зб. матер. Конф. «Міжнародний правопорядок: сучасні проблеми та їх вирішення. До 125-річчя від дня народження Володимира Михайловича Корецького», 19 лютого 2015 р. / упор. І. М. Проценко; за ред. Ю. С. Шемшученка, В. Н. Денисова. - Львів : СПОЛОМ, 2015. - С. 78-84.

8. Тихомиров Ю. А. Международное и внутреннее право: динамика соотношения // Правоведение. - 1995. № 3. - C. 56-66.

9. Малишев Б. В. Правова система (телеологічний вимір) : моногр. - К. : ВД «Дакор», 2012. - 364 с.

10. Endicott T. The impossibility of the Rule of Law // Oxford Journal of Legal Studies. - 1999. - № 4. - Vol. 19. P. 1-18.

11. Шумило М. М. Міжнародні стандарти у сфері соціального захисту // Університетські наукові записки. - 2012. № 3 (43). - С. 243-249.

12. Волошенюк О. В. Гармонізація та уніфікація законодавства як форми зближення правових систем // Право і суспільство. - 2015. - № 4. - Ч. 4. - С. 3-7.

13. Луцьь Л. Основні заходи та способи європейської правової інтеграції // Право України. - 2002. - № 5. - С. 146-148.

14. Кузнєцова Н. С. Проблема відповідності цивільного законодавства України стандартам європейського права // Університетські наукові записки. - 2005. - №№ 1-2. - С. 66-69.

15. Пакерман Г. А. Определение понятия «унификации права» в современных условиях экономического развития // Studii Juridice Universitare. - 2011. - №№ 1-2. - С. 159-176.

16. Ющзк О. I. Уніфікація у праві // Великий енциклопедичний юридичний словник / за ред. акад. НАН України Ю. С. Шемшученка. - 2-ге вид., переробл. і допон. - К. : Вид-во «Юридична думка», 2012. - С. 945-946.

\section{References}

1. Babenko K. Konstytutsiini osnovy rozvytku ta rehuliuvannia sotsialnykh vidnosyn // Viche. - 2008. - № 2. - S. 3-6.

2. Krakovska A. Ye. Sotsialni prava liudyny i hromadianyna yak vyznachalna determinanta evoliutsii sotsialnoi funktsii derzhavy // Visnyk Donetskoho Natsionalnoho universytetu. - Seriia V: ekonomika i pravo. - 2002. - Vyp. 2. S. 394-399.

3. Caher H. F. Social'noe pravo i spravedlivost' // Obshchestvennye nauki za rubezhom. - Ser. 4. Gosudarstvo i pravo. M. : INION AN SSSR, 1990. - № 3. - S. 9-13.

4. Onishchenko N. M., Parkhomenko N.M. Sotsialnyi vymir pravovoi systemy: realii ta perspektyvy: monohrafiia / vidp red. Yu. S. Shemshuchenko. - K. : Vyd-vo «Iurydychna dumka», 2011. - 176 s.

5. Khoma N. M. Modeli sotsialnoi derzhavy: svitovyi ta ukrainskyi dosvid : monohrafiia. - K. : Vyd-vo «Iurydychna dumka», 2012. - $592 \mathrm{~s}$.

6. Denysov V. N. Mizhnarodne pravo yak skladova chastyna pravovoi systemy Ukrainy // Problemy harmonizatsii zakonodavstva Ukrainy z mizhnarodnym pravom: Materialy nauk.-prakt. konf. (zhovten, 1998). - K. : In-t zakonodavstva Verkhovnoi Rady Ukrainy, 1998. - S. 64-68.

7. Onishchenko N. M. Do problemy vzaiemovidpovidnosti vnutrishnoderzhavnoho i mizhnarodnoho prava (teoretykopravovyi aspekt) // Mizhnarodnyi pravoporiadok: suchasni problemy ta yikh vyrishennia. Zb. mater. Konf. «Mizhnarodnyi pravoporiadok: suchasni problemy ta yikh vyrishennia. Do 125-richchia vid Dnia narodzhennia Volodymyra Mykhailovycha Koretskoho», 19 liutoho 2015 r. / upor. I. M. Protsenko; za red. Yu. S. Shemshuchenka, V. N. Denysova. - Lviv : SPOLOM, 2015. - S. 78-84.

8. Tihomirov Yu. A. Mezhdunarodnoe i vnutrennee pravo: dinamika sootnosheniya // Pravovedenie. -1995 . - № 3. S. 56-66.

9. Malyshev B. V. Pravova systema (teleolohichnyi vymir): monohrafiia. - K. : VD «Dakor», 2012. - $364 \mathrm{~s}$.

10. Endicott T. The impossibility of the Rule of Law // Oxford Journal of Legal Studies. - 1999. - № 4. - Vol. 19. P. 1-18.

11. Shumylo M. M. Mizhnarodni standarty u sferi sotsialnoho zakhystu // Universytetski naukovi zapysky. - 2012. № 3 (43). - S. 243-249.

12. Volosheniuk $O$. V. Harmonizatsiia ta unifikatsiia zakonodavstva yak formy zblyzhennia pravovykh system // Pravo i suspilstvo. - 2015. - № 4. - Ch. 4. - S. 3-7. 
13. Luts L. Osnovni zakhody ta sposoby yevropeiskoi pravovoi intehratsii // Pravo Ukrainy. - 2002. - № 5. - S. 146-148.

14. Kuznietsova N. S. Problema vidpovidnosti tsyvilnoho zakonodavstva Ukrainy standartam yevropeiskoho prava // Universytetski naukovi zapysky. - 2005. - №№ 1-2. - S. 66-69.

15. Pakerman G. A. Opredelenie ponyatiya «unifikacii prava»v sovremennyh usloviyah ekonomicheskogo razvitiya // Studii Juridice Universitare. - 2011. - №№ 1-2. - S. 159-176.

16. Yushchyk O. I. Unifikatsiia u pravi // Velykyi entsyklopedychnyi yurydychnyi slovnyk / za red. akad. NAN Ukrainy Yu. S. Shemshuchenka. - 2-he vyd., pererobl. i dopon. - K.: Vyd-vo «Iurydychna dumka», 2012. - S. 945-946.

Данич О. Ф. До питання про роль правової системи у забезпеченні соціальної функції держави: глобалізаційний вимір

У статті досліджуються роль та значення правової системи у забезпеченні соціальної функції держави в контексті сучасної глобалізації. Автор констатує, що при забезпеченні соціальної функції держави в умовах глобалізації національна правова система виконує найважливішу роль, яку не можна обмежувати лише характером її внутрішнього впливу на здійснення соціальної політики. Останнє пов'язано, зокрема, з тим, що особливої значущості в умовах глобалізації набувають різноманітні питання, пов'язані з конвергенцією правових систем між собою та поступовим формуванням на цій основі наднаціональних або міжнародних правових систем.

Ключові слова: правова система, глобалізація, соціальна функція держави, рівність, гідність, права і свобод людини.

Danich O. O. the role of the legal system in ensuring the social function of the state: the globalization dimension

The article examines the role and significance of the legal system in ensuring the social function of the state in the context of modern globalization. If we talk about the scientific understanding of the role and significance of the legal system in ensuring the social function of the state in the conditions of globalization, then in this case, legal influence cannot be limited only by the domestic (internal) parameters or mechanisms. After all, globalization is a global process of qualitative changes in all major spheres of social life, aimed at their unification or, at least, a combination within the framework of specific legal, institutional, ideological and other principles.

One of the ways of implementing international standards in the field of social protection is the harmonization of national legislation with international legal acts, which can be carried out in several ways: direct application after ratification, inclusion in the text of laws, implementation of ratified or unratified acts in national legislation.

Harmonization of legislation does not mean the identity (uniformity) or the identity of the content of the legal norms of the various normative acts, but involves reducing the differences between them, combining and complementing their semantic load in order to ensure the integrity and coherence of the legal regulation of the relevant sphere of public relations. In addition, the harmonization of legislation should precede its unification, especially in the context of comparing the norms of national and international law or the norms of national legislation with the norms of legislation of other states, and the latter (unification), in the case of an international component, can only be applied if there is a positive experience of harmonization of legislation, that is, as the final consolidation of its positive results in the form of the creation of uniform (identical, unified) legal norms.

At the same time, harmonization and unification, regardless of the level of their application in the legal context, should take into account not only the features of a concrete legal reality within the defined temporal-spatial dimensions, in particular, the development of branches and institutions of private and public law, the peculiarities of the implementation of ertain principles of law within the respective state, etc., but also the objective parameters of the functioning of such subsystems of social development, as economic, political, cultural, moral, religious, etc.

Thus, while ensuring the social function of the state in the conditions of globalization, the national legal system fulfills an essential role that cannot be limited only by the nature of its internal influence on the implementation of social policy, because special significance under the conditions of globalization becomes diverse issues, related to the convergence of legal systems among themselves, the gradual formation on this basis supranational or international legal systems, as well as the complication of the relationship between international and national law in connection with the objectivity of reflection in the last historical, economic, social, cultural, religious and other peculiarities of social development.

Key words: legal system, globalization, social function of the state, equality, dignity, human rights and freedoms.

DOI: 10.33.66.3/2524-017X-2019-10-121-127 